\title{
A Practical Comparison between Islamic and Christian End-of-Life Moral Guidelines towards Harmonization of End-of-Life Care
}

\author{
SUMMARY
}

This paper aims to identify common ground on end-of-life issues between the Islamic and Christian cultures. Since these two cultures are more and more coming to live in the same countries, it is important to acknowledge common ground since the laws of countries apply to all. The paper will deal with several issues, including the stopping of futile treatment, the administration of ordinary and extraordinary care, defining the difference between death and allowing one to die, and accepting death as sometimes being an inevitable and acceptable outcome. The paper will also discuss palliative care including pain relief and sedation. From here one delves into the case of Persistent Vegetative States and the morality of overenthusiastic treatment which pushes people into this state.

It will also focus on the differences, such as passive euthanasia and analyze whether this is merely a difference in the interpretation of terms. There is also a phenomenon in some countries on querying the removal futile treatment and on lacking a legal framework in general on end-of-life. At least one study shows concern on religious moral grounds. The conclusion attempts to identify the common grounds on the end-of-life and whether morality and laws in this regard are guided by religious positions. It is important that laws respect the moral normative values of populations, especially with pressure coming from more liberal positions. Even if practices such as euthanasia (the discussion of which is not the scope of this paper) are introduced in countries, it is important that health care (and legislation) recognizes the common moral ground, the lack of which may lead to more suffering.

Keywords: end-of-life, Islamic cultures, Christian cultures, passive euthanasia, palliative care.

* Correspondence Address: Pierre Mallia, Bioethics Research Programme, Faculty of Medicine \& Surgery, University of Malta, Block A, Level 0, Mater Dei Hospital, Tal-Qroqq, Msida MSD 2090, Malta. E-mail: pierre.mallia@um.edu.mt. 


\section{Introduction}

With the internationalization and globalization of medicine and advances in ability to keep people on life support, end-of-life issues necessitate more relevant reviews. The concept of whether one should keep someone on life support until brain death was challenged early on in the case of Karen Ann Quinlan - a case which is recognized as a historical landmark finding its citation in the Routledge Encyclopedia of the History of Medicine (Bynum, Porter 2001) and which was the first case in which an American court of law recognized the teaching of a traditional religion over and above scientific learning (in this case waiting until Karen would have been braindead).

By 'internationalization' one refers to the transfer of people between countries. Immigrant doctors, or those who become doctors, will generally inherit traditional customs and religions which are thus imported into countries which in turn become multicultural. This is a phenomenon, for example (but not limited to), of doctors from ex-colonial countries who travel to the United Kingdom and still have 'Royal College' membership examination. Many others go to the United States. End-of-life decisions are carried into cultures, and different Christian and Muslim countries have had to evaluate these decisions according to their culture and religious perspectives and reach important conclusions. Although there are subtle differences and at time disagreements, on the whole one sees that there is a general agreement between these religions, but as seen here, different definitions, most notably when it comes to defining passive euthanasia can create confusion.

Conversely, with the increasing scope of globalization (which is the spread of cultures across geographical areas and which includes the increase in communication and more easily available and faster means of movement of people), a harmonization of end-of-life morality is also deemed necessary in order to arrive at coherent clinical/ ethical judgments giving us a more 'global ethics'. It is not merely the religious and philosophical questions that should concern us however, but the actual practice and when and where it fails, and why. However the scope of this paper is the former; the latter has been accepted as an Erasmus + proposal which has been commenced in the fall of 2015 (Mallia 2015). Before harmonization is accepted one has to reckon on the challenge of cultures and religious points of view and whether indeed there is any form of agreement on the main issues. For example, Walker and Lovat (Walker, Lovat 2015) have made a point of proposing the concept of ordinary versus extraordinary treatment as being an ideal path in most situations, including cultural. Conflict is not however that easy to resolve as it often arises because of difference in values; it is not merely a dispute. You can resolve a number of disputes with the main conflict remaining there (Tillett 2002). It is perhaps the lack of understanding of the 
underlying values which people hold, including health care professionals, which may be of the main concern. Does my religion allow me to terminate this treatment or to remove this drug which the doctor is saying is futile?

In order to reach some form of resolution, a comparative analysis between the various cultural/religious points of view is important. One appreciates that religions have been on the avant-garde of these moral issues. Here, the aim is to deliberately compare the Christian and Muslim religions, appreciating that the Judeo-Christian model would have served as well. Of course, one admits that other religions play an important role but these two major religions, which have often been at loggerheads over theological points, find themselves interacting more and more. There is probably more positive interaction than the media or extremist groups would want the world to believe and it is interesting to observe the overlap. Truth telling, though, a compelling cultural issue is not discussed in this paper as it focuses more on religious moral teaching: pain relief, futile treatment and extraordinary treatment.

\section{Method}

The methodology used is not to compare and contrast various theological positions from both religions. Given that theologians can provide interesting perspectives in both camps, these are ongoing dialogues and do not reflect official (or traditional) positions which can, at the end of the day, help clinicians, patients and their families understand what can and cannot be done on moral grounds at the end-of-life without breaching their cultural and religious values. This is important from a clinical ethics perspective and therefore the main methodology used here is a search for authors who have discussed the more official positions of the respective religions. The literature and sources which discuss the official positions was therefore consulted. It is important to note that a small separation has been made under Christian denominations - namely the Catholic and other Christian denominations at points. The reason is that when referring to Christianity we refer to a cluster of different denominations (including Catholic), some of which tend to be post-traditional (Engelhardt, Smith Iltis 2005). This follows the treatment of reviews on end-of-life by The Lancet in 2005, in which the Catholic point of view was treated separately, as it was felt that reference to Catholic traditions sometimes merited to be distinguished from the general group of 'Christian'. This should be understood further in the next paragraph. 


\section{Respective backgrounds on Life}

Many papers, which have analyzed end-of-life issues from the Islamic Perspective invariably, and rightly-so, start from the underlying religious concept of life and death

(Sachedina 2005, Bagheri 2013, AtiGhetchi 2007). Muslims believe they were created to discover God's work in the universe and to appreciate and serve God's ends. From time to time God sends prophets, and the prophet Mohammed, founder of Islam, is the last one in this line of prophets. Life belongs to God and its willful termination is therefore prohibited. Neither, however, must one accept death. Practices of euthanasia, voluntary or involuntary, are thus prohibited. The debatable questions arose mostly in the context of health care, especially with hospitalized patients who may or may not be given care, which can be considered extraordinary. Muslim legal scholars are under pressure to respond to questions relating to health care with the onset of advancing medical technology (Ibid.). This is especially so in questions relating to the end-of-life. Their deliberations fall under the auspices of the Islamic Juridical Council (IJC), which is an organ of the Organisation of Islamic Conference (OIC), in which jurists from different schools of thought respond coherently to specific problems and situations. These are published in a quarterly journal issued by the IJC. The Quran recognizes the limits of human nature and that pain is a form of test or trial. We shall see that this has not however prevented the use of pain relief; also because jurists agree that traditional Islamic teaching cannot cater for new circumstances and developments. Islam is inherently discursive and pluralistic (Ibid.).

One finds the same debates in Islam that one finds among Christians on end-of-life. However, the latter is complicated by the ambiguity of the term Christian, which encompasses a number of groups which 'at best' share resemblances (Engelhardt and Smith Iltis 2005). There are Unitarians, Seventh-day Adventists, Anglicans, Mormons, Lutherans, Orthodox, etc., not to mention Catholics. These groups differ in theology and indeed on end-of-life decisions. However, many Christian groups can also be seen as traditional, and whilst these will not, for example, accept euthanasia, the post-traditional groups, such as the Unitarian, will. According to Engelhardt, a failure to acknowledge difference amongst Christians can lead to end-of-life decisions which patients and families will reject. Christianity has always affirmed the importance of health care, but since the constructions of the first hospitals, there has always been intense discourse on new developments. Miller, in his book on 'The Birth of the Hospital in the Byzantine Empire' (Miller 1997) points out that although Christianity became a pioneer in the cure of the sick in hospitals, and religious orders were dedicated to being 'hospitallers' bringing the practice of 
medicine in a 'thoroughly Christian environment', there were many Christians who at the time of the first hospitals felt that pagan science was entering Christianity and that the only healer was Christ himself. This was especially for the Byzantine Christians. Eventually, Alexandrian theologians of the third century and the "Greek Fathers" of the fourth gave their blessing to medicine, giving it a paragon of charity.

Today's Catholic religion also finds different theological and philosophical methodologies resulting in differences of opinion; but one tends to find coherence on end-of-life issues (Markwell 2005). Catholics are thought to remain attuned to the message of Christ and pain is also seen as being redemptory. This also gave rise to the controversy on sedation at the end-of-life, which may inhibit a dying patient from making redemptive attempts. Markwell points out the two basic values that predominate in Catholics bioethics - that of human dignity, and the interconnectedness of every individual. The human person is called into a relationship with God. Theologians have been discussing end-of-life issues at least since the $16^{\text {th }}$ century, when the extraordinary measures meant also that families did not need to go through the expense that they could hardly afford to treat the ill. This is further discussed below. However, Catholics see that physical life is not an absolute good to be preserved at all costs and that God participates in the human condition through Jesus Christ, who is His incarnation. The value of charity and solidarity demand however that one responds to the needs of others, especially the poor and needy, including the sick. This is why the doctor-patient relationship is seen better as a covenant rather than a contract, and is the reason for virtue ethics being given prominence over principlism more recently (Pellegrino 2009).

Christians (in general) prohibit all forms of assisted suicide and forbid saving life at all costs. Catholicism believes in the sanctity of life, as a gift and creation of God. One does not own one's body. We have seen that amongst protestant groups some have advocated for passive euthanasia. We shall see that whilst there may be general agreement against active euthanasia, there is a problem with passive euthanasia as is also seen in the Islamic tradition; although one accepts removal of futile treatment as important in general, it still falls into a category of passive euthanasia, but which is granted an exception (Zahedi, Larijani \& Tavakoly Bazzaz 2007 p. 49). This merits some analysis in the paragraph on extraordinary care when trying to reconcile teaching to form common moral ground at a global level in order not to be caught in the definitions.

It is also noteworthy that the Catholic Church gave its teaching a more formal form in 1952 when Pope Pius XII made a clear and ample clarification to doctors. This was important for Western countries which were predominantly Catholic. But this does not mean that Catholics do not differ nowadays - it is mostly a matter of either 
ignorance of what the Church has actually been saying and indeed a difference in interpreting the teaching. The case of Karen Ann Quinlan was indeed a historical case because it was the first time in the United States that the court upheld a religious (Catholic) teaching of extraordinary care (as that of a social institution) as opposed to the scientific 'teaching' that death on life support is seen through the concept of 'brain death'. Quinlan was thus not scientifically dead, but it was admitted that she was being given extraordinary treatment which was keeping her alive in a futile sense. One wonders whether this would have been possible without the 1952 assertion. Even giving too much treatment and pushing patients into a vegetative state was seen as morally wrong and repudiated under Pope Paul VI (Petrini 2011).

But paradoxically, the more recent controversy over artificial nutrition and hydration (ANH) has brought about the concept that unless physiologically futile or burdensome, people in PVS should be given ANH (Shannon, Kockler 2009, p. 153), even though there was a window of opportunity, as it were, when the patient was at a stage when he/she could have been taken off life support - keeping in mind of course that persistent vegetative states are always a side effect of over enthusiastic medical care and do not occur naturally without emergency and continued treatment.

Catholic doctrine however is clear on the main concepts, but interpreting the Magisterium, which is the formal teaching of the Catholic Church (Magisterium of the Catholic Church 1994), has proved problematic with Artificial Nutrition and Hydration (ANH), what is futile, and how much one ought to treat people who are in danger of falling into a Persistent Vegetative State (PVS) or are already diagnosed with such a condition. Whilst, therefore, in 1952 it was asserted that one cannot treat patients without their formal consent or without the consent of the family if the patient is unable to make decisions, and that the patient decides what ought to be extraordinary or not for him, more recent declarations have sought to make hydration as an 'ordinary' care. Although there have been clarifications by the Church, many practices in hospitals fear removing hydration, with most people dying with a drip still attached to their arms, not taking into consideration the discomfort it may produce inherently or simply to insert another needle in order to maintain it (Ballatt, Campling 2013).

\section{Paternalism vs. rights}

In order to emphasize the misconceptions on how people interpret morality and perhaps the predominant paternalism in maintaining some treatment whilst withholding other, one need only look again at PVS. It is interesting that whilst ANH is advocated in PVS, many then assume that giving an antibiotic may be 
extraordinary and not necessary. This is paradoxical and perhaps immoral. It really depends on the policy of the hospital on how to deal with PVS and the budget one has for doing so. If one is keeping a PVS patient alive because of human dignity why should not one treat the flu or an infection? Clearly the 'fight' against death has given rise to PVS being almost accepted and no one seems to question the moral implication (or whether it is indeed morally wrong) to over-treat a patient to the point of sending him or her into a vegetative state. Conversely, Robert Veatch has indeed pointed out that when relatives of dying patients challenge medics and hospitals who wish to remove futile treatment, courts in the United States have been willing to accede to the wishes of the relatives (Veatch 2013). He notes that in the 70's, families fought for the right to refuse medical treatments which were seen merely as prolonging the dying process. The situation has changed over the years with families challenging doctors who believe that the treatment is futile. There is a paradigm shift therefore from physiological futility to normative futility - a futility which is discussed on the rights and philosophical basis rather than an epistemological and physiological basis. It should be pointed out however that this article avoids this argument, which may perhaps, it is contended, arise due to lack of moral education on the part of the public (i.e. a lack of understanding what their own religion is saying, presuming that they adhere to one). From a liberal perspective there is little one can do but to appeal to a more secular ethic, arguing and explaining futility as was done in the 70's - that it merely prolongs the agony.

What follows is a critical appraisal of specific aspects of end-of-life care in order to tease out the common moral ground in the hope of a harmonization which may help multicultural societies and on broader grounds.

\section{Killing and allowing to die}

Both Christian and Islamic traditions distinguish between killing and allowing to die. Atighetchi explains that every Muslim doctor must make all efforts to save a patient from dying if the probabilities of success appear significant and that on the contrary artificially prolonging the vegetative state of a person is unlawful as it is consciousness that makes an individual responsible (AtiGhetchi 2007) (p. 271). This contrasts with Catholic teaching as stated above, notwithstanding that the Church had pronounced itself against pushing people into a vegetative state. Of course, the perception that hospitalized care has become less and less 'extraordinary' may have had an influence on this. Public perception of intensive care may indeed be accepted and thus demanded by relatives who do not have to pay directly for it. 
Sachedina points out that the medical judgments about death are based on probability, and a doctor can only predict that death is imminent when it is very close. He states that, 'Hence, the Qur'an offers a sober reminder that there are times when human beings need to recognize their own limits and entrust nature to take its own course (Qur'an 39:42)' (Sachedina 2005 p. 776). Refusing to recognize that inevitability and naturalness of deaths lead to more aggressive treatments (which in turn can lead to a vegetative state), but however to withhold a specific intervention at a crucial time which may be life-saving results in 'deliberate avoidance of responsibility'. Life support, he asserts, can be turned off when physicians are certain about the inevitability of death.

Christians have long asserted that a doctor does not violate any moral rule if by recognizing that death is inevitable one allows a person to die (John Hinton 1967). Of course, this does not imply that one should forego life-saving treatment. It only means that prolonging life for the sake of fighting death is not good moral practice. In this regard one should perhaps consider the difference of various practices when people choose to die at home. It is understood that one cannot offer the same endof-life care at home as one can in hospital. Unless there are good and continued community palliative care services at one's home, one cannot have even intravenous lines for hydration, although pain relief can easily be provided intramuscularly. So, it is understood that hospitalization can prolong a dying person's life by a few days. This practice is accepted in most Christian and Islamic countries. However, people can often choose for their relative to die in hospital not only because of the burden of having a relative die at home, but because they may feel they are doing their best for their relative. Once at hospital the medical team may feel obliged that this perception is respected and therefore inevitably intravenous lines go up for hydration and nutrition. One finds it difficult to accept the moral equivalence of removing these drips as it seems to deceive the end of doing one's best, notwithstanding that thrombosed veins can mean that the dying person is punctured by a needle several times each time one wants to re-insert a new venflow when the other has become blocked.

From a Muslim perspective, Atighetchi conversely points out that whilst many people feel that if for the dying person his or her environment makes the process less burdensome, homes do not have the 'modern clinical equipment' and therefore this inclination to keep the person at home is not without its 'problematic consequences' (Ibid. p. 271). Whilst sending someone to hospital can relieve the burden from the family, there is also the question whether this constitutes a 'discard' and therefore in 'insidious form of passive euthanasia'. Conversely, he also points out that in Tunis, in order to avoid scenes by relatives at hospital, doctors may suggest that the dying patient is taken home, finding solace in a decree which allows this transfer 
if the patient or relatives request it. It is a matter of what is in the best interests of the patient. One does however notice the tensions between what is considered appropriate or disproportionate does give rise to doubt about whether this is some form of passive euthanasia.

It seems therefore that there is no real moral contention about dying at home in each religion. In fact many do prefer to die at home and can forego treatment on the mere basis that they may deem hospitalization itself to be burdensome. The relatives do indeed come into play when the person approaches death and is unable to communicate well. Their decision whether to send the patient to die in hospital may be based on burden or otherwise. Sometimes they cannot respect the patient's wish to die at home for practical reasons. For example, in the practice of the author an 86 year old gentleman who was semiconscious refused nappies and each time he needed to pass urine or stool, his daughter, who lived alone with him, needed to call her uncles to help her lift him from bed. The patient did on this occasion die before being sent to hospital. The problem would have been twofold - that the patient's wish could not have been acceded, and that there would have been the risk that the patient be subjected to investigations, drips and so on.

\section{Disproportionate treatment vs. passive euthanasia}

The Catholic position on this issue is very clear (as evidenced above) (Magisterium of the Catholic Church 1994): 'Discontinuing medical procedures that are burdensome, dangerous, extraordinary, or disproportionate to the expected outcome can be legitimate; it is the refusal of 'over-zealous' treatment. Here one does not will to cause death; one's inability to impede it is merely accepted. The decisions should be made by the patient if he is competent and able or, if not, by those legally entitled to act for the patient, whose reasonable will and legitimate interests must always be respected.'

Amongst Christians end-of-life decisions are sometimes controversial. Engelhardt and Smith Iltis point out that whilst some protestant groups clearly oppose euthanasia and assisted suicide, others accept passive but refuse active euthanasia. Still others accept active euthanasia as a personal choice. There is also controversy about withholding ANH as many see it as an intention to cause death. Traditional Christians (see introduction for distinction) have never intentionally caused death. Catholic teaching on withholding or withdrawing treatment has been around since the $16^{\text {th }}$ century at least, as pointed out above. Patients can choose what is ordinary and what is extraordinary (which includes excessive expense, pain or other inconvenience), especially if it does not offer reasonable hope. Markwell points out that 'ordinary' was originally used to mean 'what is medically customary' and perhaps 
this is the main problem with nutrition and hydration and even other methods which are viewed as extraordinary but which many (including doctors) have come to see as 'customary'. This of course creates problems beyond the mere cultural and religious but is more of a sociological tendency promulgated by the high hopes people have in hospitals and medicine and which may explain Veatch's observation that courts of law tend to agree with patients and relatives when hospitals decide to forego some treatment considered futile.

Whilst many countries like the United Kingdom have clarified end-of-life issues in their General Medical Council guidelines, other countries are not very clear at all. The main issue is often with ANH. Why this is so, is mysterious; after all oxygen is as much important for life as water and nutrition, and whilst dying people do not normally drink or eat, they usually still breathe. Indeed, dying of suffocation is probably more 'painful'. Yet the cases in which people have legitimately refused artificial ventilation even when conscious are surrounded by controversy. This practice has been recognized in the UK (Howard, Bogle 2005). Whilst Dianne Pretty had been refused because her case was not one of refusal of treatment but one of asking for termination of her life, Mrs. B was permitted to refuse artificial ventilation based on the right to refuse treatment. Conversely, in Italy, the Church did not recognize the same appeal of Mr. Piergiorgio Welby. On the other hand, medically assisted nutrition and hydration should be seen as optional if they become excessively burdensome and cause physical discomfort (United States Conference of Catholic Bishops 2009). The issues restrict themselves to end-of-life only and not to the quality of life, although there are contradictions between the McAffee and the Welby cases. Clearly however, disproportionate or extraordinary care and even that which is an ordinary care but becoming burdensome are allowed under Catholic and other religions' moral guidance. It is not a case of passive euthanasia, as the same actions are in a quality of life issue.

There is a clear difference of nomenclature when one compares Islamic cases of disproportionate and burdensome treatment. Whereas generally these are allowed, it is still labeled by many authors as 'passive euthanasia'. Zadehi et al (Zahedi, Larijani \& Tavakoly Bazzaz 2007) point out that whilst some Muslim scholars assume that Islamic law permits the withdrawal of disproportionate treatment on the basis of the consent of the family, and whilst, as pointed out above, the Muslims distinguish between killing and allowing to die, killing is seen as euthanasia and allowing to die as passive euthanasia.

This distinction is pointed out by other authors writing on generally accepted Muslim teaching. Sachedina (Sachedina 2005, p. 776) points out that the distinction between 'killing (active euthanasia) and letting die (passive euthanasia)' often distinguishes 
between 'suicide and foregoing treatment or between homicide and natural death'. He says that there are two important instances that 'could be interpreted as passive assistance...but that would not result in criminal charges' (italics author's). These are pain relief and removing a death delaying treatment following discussion with the patient and/or the family when death is inevitable. We have seen that Atighetchi has implied that for some, allowing people to die at home can be interpreted as passive euthanasia because they are denied hospital care. But he shows that this is not always practical and patients and families do seem to have a choice here as well. Yet the word 'passive euthanasia' is used in a negative sense as well. He again recognizes that most Muslim scholars will allow this passive euthanasia in case of futile treatment - whilst relatives 'frequently request extreme treatment in the hope of recovery of a dying patient' and that whilst some Muslim scholars believe that 'every possible effort should be made for the survival of the patient', 'others introduce the categories of unnecessary, ineffective or inappropriate measures when the patient is in the final throes'.

There is clearly lack of guidelines on extraordinary measures in many countries of both denominations. Doctors may fear lack of legislation when it comes to removal of futile treatment (Ballatt, Campling 2013) (p. 116). Bagheri notes that the concept of futility has caused problems not only in how to define what is futile, but also when and how to apply it (Bagheri 2013 p.264). Withholding and withdrawing life support in Iran is controversial but whilst there is a general dominancy of physicians (which Bagheri refers to as a medical paternalism - and hence of societal significance), the general idea among physicians is that medical futility should be based on physiological futility. It is thus not a value judgment but an objective one. Many physicians also emphasize the role of the family. Abuhasna and Abdulkareem Al Obaidi (2013) also argue for the need of legislation in the United Arab Emirates and they advocate for a national policy based on physicians' attitudes and the patients' perception to clarify futile treatment and end-of-life decisions. These authors argue that there is growing awareness of the importance for guidelines on end-of-life issues and in general there is agreement that families should be involved in the decision making process. They say that although from an Islamic perspective that are no clear guidelines on end-of-life care for the Muslim patient, many scholars agree that withdrawal of life support and futile treatment is acceptable in cases where physicians agree that the patient has died (p. 251). When it comes to futile treatment critical care physicians have argued that it is important to involve the family of the terminally ill patient and have advocated for 'optimal education of patients and their families', which often resolve these issues. Perhaps, under optimal education they mostly refer to good communication and empathy. In general, they say that there is a growing understanding of medical futility in UAE countries. 
As a final example of an Islamic country, Turkey presents an interesting position. There is no legislation which covers end-of-life removal of futile treatment (Arda, Aciduman 2013). Discussions on DNR orders are usually between physicians themselves according to cited studies. A Medical Deontology Regulation of 1960 makes it very difficult for physicians to limit or withdraw life support (Bagheri 2003, p. 242). In fact there is no law which covers medical futility and that allows the withdrawal of treatment considered to be futile. Whilst euthanasia is considered a crime, it is not the case in everyday practice, 'it is possible to state that passive euthanasia is exercised in certain cases'.

These comparisons clearly show that there is a difficulty in the nomenclature. However, this distinction should not be taken too far. Clearly Christian denominations distinguish between passive euthanasia and removing futile or extraordinary or disproportionate treatment. Passive euthanasia remains wrong and is restricted to define situations in which the end has not yet approached. Conversely Muslim scholars are in general agreement about the legitimacy of removing futile treatment and the permissibility of not given extraordinary care in order not to prolong the agony, but clearly do refer to these as passive euthanasia. This is true for the most Muslim countries. A global understanding of end-of-life care should therefore address this issue of nomenclature. But, on the other hand, although a moral position is clear in many Christian countries, health care professionals may be more concerned with legal positions. There is less medical paternalism so patients and their relatives can certainly challenge removal of futile care. Conversely, there may be lack of one's own moral understanding of what is licit. In all denominations therefore, families and even physicians may see removal of futile treatment or extraordinary case as passive euthanasia and preoccupy themselves with moral and legal positions. This certainly holds true for Christian cultures as has been seen for Muslim cultures showing the need for not only educating health care professionals but providing support and general media education to the general public and encouraging legal change.

Whilst religions may differ on whether removing extraordinary treatment is defined as passive euthanasia or not, they generally agree with its moral appropriateness. There is however a lack of local legislation and more modern ideas of what is commonly seen as customary in medicine may come to be requested more with people making higher demands on health care.

\section{Pain management and sedation}

The concept of pain management in many countries remains elusive. Although there is no evidence that pain management may hasten death, this notion has provided 
moralists in many religions some thought. The Catholic religion acknowledges that even if giving pain relief can bring about an earlier death, it follows the principle of double effect in which the intention is to relieve pain and the harm is foreseen but unintended. It remains morally acceptable and is seen as a charitable thing to do. Yet, lack of education in this regard entices fear in many relatives and health care professionals.

Kirchheimer (Kirchheimer 2004) argued about a decade ago that end-of-life care remains best in hospice services. In other institutions studies showed that nearly $25 \%$ did not receive an adequate treatment. When considering that some patients need minimal pain relief this percentage may even be a low reflection if one had to study patients who only needed higher doses of pain relief. Thomson (Thomson 2001) had also pointed out that there is a large gap between what patients desire at the endof-life and what the system actually delivers when it comes to pain management. She quotes a survey of oncologists saying that $76 \%$ of physicians rated poor pain assessment as the single most important bar towards adequate pain management and $86 \%$ felt that patients were under-medicated. She laments the lack of attention to pain given in medical school curricula and the lack of its assessment. In one study trainees show great interest in receiving training on palliative care (Mallia, Abela 2011, Abela, Mallia 2010).

Lack of appropriate training was reflected on the implementation and failure of the Liverpool Care Pathway (LCP), which was introduced in the UK. Whilst many British people receive end-of-life care in hospices, these, being charities, are more frequently found in the relatively richer areas of the UK. Poorer communities were still resorting to hospitalized care at the end-of-life with the result that an attempt was made to introduce palliative care in hospitals, hence the Liverpool Care Pathway. As the name implies it was a 'pathway' recommending certain steps depending on deterioration and situations. Being a palliative care pathway, and recommended by the National Institute of Health and Care Excellence (NICE) guidelines, it needed an adequate training even for qualified doctors. This turned out not to be the case. The result was that in many places implementing the LCP meant an immediate termination of treatment, hydration and even giving sedation. It was thus quickly accused of becoming a euthanasia pathway. It was subsequently removed (Saunders 2013). The document One Chance to Get it Right was the result recommending to introduce an adequate training on pathways and communication.

The American Medical Association Journal of Ethics reported common misconceptions about pain management, with concerns about pain relief at the cost of consciousness or length of life (Berger, Vadivelu 2013) clearly showing the current lack of moral understanding and education among health care professionals. 
Moreover, the concept of palliative sedation gave rise to strong debate about whether this constitutes a euthanasia practice. Ten Have and Welie (2014) discussed this concept in depth in the Journal of Pain and Symptom Management. They argue that the ethical differences between palliative sedation and euthanasia are implicit. However, the concept did give rise to concerns that the practice may verge on euthanasia. They rebut this conclusion but do point out that if physicians resort immediately to sedation to circumvent existential suffering without previously trying other adequate alternatives, and also insist on removing artificial nutrition and hydration, then it will be difficult to argue that their intent is solely to relieve pain. This in fact explains what happened in application of the Liverpool Care Pathway. The International Association of Catholic Bioethics also released a statement saying that when titrated, palliative sedation was good practice. This makes sense as attempting to keep consciousness to give a chance to the patient to redeem himself is naive when he or she is already under the influence of drugs (Sullivan, Heng 2013).

This concern with removing consciousness is mostly a religious one and is also reflected in Islamic practice. Many Muslim authors point out that pain is redemptive but have still concluded that end-of-life removal of pain is consistent with Islamic teachings. Zahedi et al (Zahedi, Larijani \& Tavakoly Bazzaz 2007) argue that 'pain functions as an instrument in revealing God's purpose for humanity and in reminding us that ultimately we belong, and will return to, God.' They assert however that according to 'some' Muslim scholars, patients in pain from terminal illness may receive pain management. Sachedina (Sachedina 2005) is more optimistic in his analysis. $\mathrm{He}$ too asserts the same function of pain in God's plan, but says that this religious and spiritual assessment of pain does not remove the fact that the primary obligation of the physician is to remove pain. Notwithstanding this, many Muslims resign themselves to pain as they believe it purifies them and that pain should therefore be endured with patience and persistence. These religious purposes find their ways in both religious denominations and yet both speak about the usefulness of recognizing that pain management is important at the end-of-life and that it is not immoral practice even if it shortens life or removes consciousness.

Atighetchi (AtiGhetchi 2007) points out that doctors in Riyadh complained about the lack of moral awareness in their country and advocated against the fear that the use of opioid analgesics goes against Islamic principles recommend the instruction of religious authorities in order to include them in the palliative care staff. He notes the fear in many countries to resort to opioid management: in Egypt the use of morphine requires the authority of the Ministry of Health and the pharmaceutical companies so the chemists prefer not to deal with morphine out of fear of the responsibility involved. In Indonesia the recourse is made to non-steroidals and non-opioids and to the weakest opioids due to the lack of morphine. 
In the UAE Abuhasna and Ali Abdulkareem (Abuhasna, Abdulkareem Al Obaidli 2013) (p. 251) point out that symposiums and conferences have been addressing the need of adequate palliative care and other end-of-life issues. They are optimistic that there is a growing understanding for the need of a federal policy on dealing with terminally ill patients. They assert that interpreting the Qur'an shows that pain relief and sedation do not fall within the scope of euthanasia. Bagheri (2013 p. 279) also notes this interpretation of the Qur'an, agreeing with Sachedina that (as in the Christian tradition) there are two situations which although interpreted as passive euthanasia are nevertheless allowed morally - palliative pain relief and removal of extraordinary treatment.

\section{Cautionary reflections on humanists}

This paper has focused on a reflection and comparison of Islamic and Christian formal thoughts on end-of-life care. Admittedly, one needs to further this comparison on a broader aspect to include other religions, especially the other monotheistic religion of Judaism. However, this paper will not be complete without a small caution on humanists. Humanists are those people who consider themselves atheists but who still have concern about a moral life. They may not believe in after-life but they have strong moral values. Many humanists may indeed come from families with religious backgrounds but over the course of their lives rejected religious authority and beliefs. However, one may argue that humanists inherit moral values from a western tradition. Although humanists have been traced back to ancient Greek times, their moral roots are found in the enlightenment. Certainly, although rejecting many religious beliefs, they positively embrace moral rules which build western moral thought. Humanists are not the people who believe in New Age, spiritualism, eastern religions or even embrace a belief in reincarnation. A prerequisite of a humanist is that they do not embrace any form of the supernatural.

Humanists do believe and need proper end-of-life care. Baggini and Pym (DATE) point out that they often need to talk about their death. Death is difficult for them and their families too. Whilst one should not consider that religion can do them no harm, and therefore impose some last-minute confession or last rites, it does not follow that they do not have an interest in what happens after their death. They are interested, for example, in the way they will be buried and what we say about them. One cannot assume that because some people do not have religious beliefs, then they have fewer needs than those who believe. 


\section{Conclusion}

It is clear that both the Islamic and Christian religions are in agreement on positions of futile treatments, the appropriate distinction between ordinary and extraordinary care, and in fact the difference between killing and allowing one to die. There is also a general moral agreement on palliative pain relief and to a certain extent on sedation. None of these would be considered euthanasia. There is however some inconsistency in terminology. Whilst Christian denominations distinguish between passive euthanasia (which remains wrong) and the appropriateness of the above practices, Muslim traditions continue to refer to them as (permissible) instances of passive euthanasia. However, there are also similar fears of the lack of legislation and in this regard similar concerns about insufficient moral teaching.

Conversely, patients or families in both religions often assert their rights to extraordinary care; sometimes in an effort to keep the patient alive and sometimes believing that not providing such care is a practice which is morally disallowed. There is thus continued need for public education, legislation, and the support and training of health care professionals and spiritual people who may come in touch with dying people. End-of-life care is a pseudo-specialty and although palliative care is a specialist area in many western countries most patients at the end-of-life dying in hospital may not receive such specialized attention. Whether it should be a specialty in its own right or a sub-specialty to be given as training to many other specialists - internal medicine, surgery, geriatrics, family medicine etc., can be the subject of another analysis. With the impact of globalization, the harmonization of end-of-life care is as important as the harmonization of general medical care. A comparison of religious moral theories is important notwithstanding the secularization in many countries. The same countries often deal with people of different cultures and respecting these cultures is important to families and patients. Bringing as more global bioethics to people via further studies, education and legislation ought to be the scope for improving clinical outcomes and ethics. 


\section{References}

1. Abela, J. \& Mallia, P. 2010, "An evaluation of palliative care education in the specialist training pogramme in family medicine”, Malta Medical Journal, vol. 22, no. 04, pp. 26-26-33.

2. Abuhasna, S. \& Abdulkareem Al Obaidli, A. 2013, "Medical Futility in the United Arab Emirates" in Medical Futility. A Cross-National Study, ed. A. Bagheri, Imperial College Press, London, New Jersey, pp. 247-247-261.

3. Archdiocese of Atlanta 1990, "Giorgia man asks to turn off life-supporting ventilator" in Quality of Life. The New Medical Dilemma, ed. James J. Walter, Thomas A. Shannon, Paulist Press, New York and Mahwah, pp. 349-357.

4. Arda, B., \& Aciduman, A. 2013, "Medical Futility in Turkey" in Medical Futility. A Cross-National Study, ed. A. Bagheri, Imperial College Press, London, New Jersey, pp. 227-227-245.

5. AtiGhetchi, D. 2007, Islamic Bioethics: Problems and Perspectives, Springer, Dorthrecht.

6. Baggini, J. \& Pym, M. 2005. "End-of-life: the humanist view", The Lancet, vol. 366, pp. 1137-1238.

7. Bagheri, A. 2013, "Medical Futility in Iran" in Medical Futility. A Cross-National Study, ed. A. Bagheri, Imperial College Press, London, New Jersey, pp. 263-263-282.

8. Ballatt, J., \& Campling, P. 2013, Intelligent Kindness. Reforming the culture of health care. RCPsych Publications, London.

9. Berger, J.M. \& Vadivelu, N. 2013, “Common misconceptions about opioid use for pain management at the end-of-life", AMA Journal of Ethics, vol. 15, no. 5, pp. 403-403-409.

10. Bynum, W.F. \& Porter, R. (eds) 2001, Companion Encyclopaedia of the History of Medicine, Vol. 2, Routledge, London, New York.

11. Engelhardt, H.T. \& Smith Iltis, A. 2005, "End-of-Life: the traditional Christian view", The Lancet, vol. 366, pp. 1045-1049.

12. Howard, P. \& Bogle, J. 2005, Medical Law and Ethics, Blackwell Publishing, Oxford.

13. Hinton, J. 1967, Dying, Penguin Books, London.

14. Kirchheimer, S. 2004, End-of-life care inadequate, Jan 6, 2004. Available: http://www.webmd.com/ healthy-aging/news/20040106/end-of-life-care-inadequate [2015, Jan 6, 2004].

15. Magisterium of the Catholic Church 1994, Catechism of the Catholic Church, Veritas, Dublin, Vatican City.

16. Mallia, P. 2015, EndCare. On Harmonisation and Dissemination of Good Practice at the End-of-Life. Project no. 2015-1-MT01-KA203-003728.

17. Mallia, P. \& Abela, J. 2011, "An Evaluation of the Palliative Care Module in the Specialist Training Programme in Family Medicine”, Malta Medical Journal, vol. 22, no. 4, pp. 26-33.

18. Markwell, H. 2005, "End-of-Life: a Catholic view”, The Lancet, vol. 366, pp. 1132-1135.

19. Miller, T.S. 1997, The Birth of the Hospital in the Byzantine Empire, The Johns Hopkins University Press, Baltimore and London.

20. Pellegrino, E.D. 2009, “Toward a virtue-based normative ethics for the health professions", Kennedy Institute of Ethics Journal, vol. 5, no. 3, pp. 253-277.

21. Petrini, M. 2011, "Il testamento biologico: status of art.", Um. Nuova, vol. 6, no. 198, pp. 621-657.

22. Sachedina, A. 2005, "End-of-Life: the Islamic view", Lancet, vol. 366, pp. 774-779.

23. Saunders, J. 2013, "The Liverpool Care Pathway", Journal of the Malta College of Family Doctors, vol. 2, no. 2, pp. 5-5-10.

24. Shannon, T.A. \& Kockler, N.J. 2009, An Introduction to Bioethics, 4th edn, Pauline Press, New Jersey.

25. Sullivan, D. \& Heng, J. 2013, "The use of sedatives in the care of persons who are seriously ill or dying. Ethical distinctions and practical recommendations. The fifth international Association of Catholic Bioethicists.", Bioethics Outlook, vol. 24, no. 2. 
26. Ten Have, H. \& Welie, J. 2014, "Palliative Sedation versus Euthanasia: An Ethical Assessment", Journal of Pain and Symptom Management, vol. 47, no. 1, pp. 123-123-136.

27. Thomson, H. 2001, "A new law to improve pain management and end-of-life care", Western journal of Medicine, vol. 174, no. 3, pp. 161-161-162.

28. Tillett, G. 2002, Resolving Conflict. A practical approach, 2nd ed., Oxford University Press, Oxford, New York.

29. United States Conference of Catholic Bishops 2009, Ethical and religious directives for Catholic health care services, 5th ed., USA.

30. Veatch, R.M. 2013, "So-called Futile Care: The Experience of the United States" in Medical Futility. A Cross-National Study, ed. A. Bagheri, Imperial College Press, London, New Jersey, pp. 9-9-33.

31. Walker, P. \& Lovat, T. 2015, "Concepts of personhood and autonomy as they apply to end-of-life decisions in intensive care", Medicine, Health Care and Philosophy, vol. 18, no. 3, pp. 309-309-315.

32. Zahedi, F., Larijani, B. \& Tavakoly Bazzaz, J. 2007, "End-of-life ethical issues and Islamic views", Iran Journal of Allergy Astham and Immunology, vol. 6, no. 5, pp. 5-5-15. 


\section{Praktična usporedba islamskih i kršćanskih moralnih smjernica vezanih uz kraj života za harmonizaciju njege na kraju života}

\section{SAŽETAK}

Cilj rada je utvrditi zajedničko stajalište između islamskih i kršćanskih kultura u pitanjima o kraju života. Budući da ove dvije kulture sve više dijele zajednički život u istim zemljama, važno je utvrditi zajedničko stajalište, jer se zakoni u zemljama odnose na sve. Rad uključuje nekoliko pitanja, uključujući prekidanje nepotrebnog liječenja, primjenu redovite i izvanredne skrbi, definiranje razlika između smrti i dopuštenju osobi da umre te prihvaćanje smrti kao ponekad uistinu neizbježnog i prihvatljivog ishoda. U radu će se također raspravljati o palijativnoj skrbi, koja uključuje ublažavanje bola i sedaciju, a u kojoj se zadire u slučaj stalnih vegetativnih stanja i moralnosti pretjerano entuzijastičnog liječenja, zbog kojeg ljudi zapadaju u to stanje. Fokus rada će također biti na razlikama, kao što je pasivna eutanazija, i analizi je li razlika samo u tumačenju pojmova. U nekim zemljama vidljiva je i pojava u vezi s propitivanjem nepotrebnog liječenja i općenito nedostatka zakonskog okvira o kraju života. U barem jednoj studiji uočena je zabrinutost zbog vjerskih moralnih razloga. U zaključku se pokušavaju utvrditi zajedničke osnove vezane uz skrb na kraju života i jesu li moralnost i zakoni u tom pogledu vođeni vjerskim pozicijama. Važno je da zakoni poštuju moralne normativne vrijednosti stanovništva, osobito pod pritiskom koji dolazi od strane liberalnijih pozicija. Čak i ako se u zemljama uvede praksa poput eutanazije (koja nije dio rasprave ovog rada), važno je da zdravstvena zaštita (i zakonodavstvo) prepoznaju zajedničke moralne osnove čiji nedostatak može dovesti do veće patnje.

Ključne riječi: kraj života, islamska kultura, kršćanska kultura, pasivna eutanazija, palijativna skrb. 